\title{
THE PECULIARITIES OF SOCIAL PERCEPTION IN THE CONTEXT OF INFORMATION-PSYCHOLOGICAL WARFARE
}

\author{
Nane Zeynalyan ${ }^{1}$
}

\begin{abstract}
In the recent decades, war fields have moved into the information sphere. Today's person has reason to "be informed"; as having information provides a sense of security. In the modern world, great effort is invested in expanding information sources, because it serves to articulate both international policies and the context of wars. The exchange of information in domestic and international platforms influences the quality of public debate and ideology, which affects social attitudes and decision-making processes. This article presents the role of information-psychological warfare as a factor in forming public opinion. It discusses the peculiarities of organizing an information-psychological warfare during military conflicts. The goal of our research is to explore how social groups might perceive peculiarities in the information-psychological warfare. The research involves methods of survey, content analysis, and free associations. The effectiveness of psychological warfare significantly depends on how people perceive information. Consequently, in the contemporary world, it is necessary to not only protect or fight on the battlefield, but also to use information weapons. This imposes requirements on psychological scientists to explore peculiarities around the perception of information to help find mechanisms that safeguard people's lives by way of contributing to the formation of necessary attitudes and stereotypes.
\end{abstract}

UDC Classification: 316.6 UDC Classification: 305-055.2 DOI: http://dx.doi.org/10.12955/cbup.v4.803

Keywords: social perception, public opinion, psychological operations.

\section{Introduction}

Today, more than ever before, individuals feel the need to "be informed", since possession of information provides a sense of security. Therefore, one tries to be aware of ongoing events in the world. Currently, continuous development of information systems provides this opportunity. The 21st century is an era highly saturated with information, as information systems form part of our everyday way of life, radically changing our lives. It is also obvious that the information era has changed the way of conducting military operations. Now, it is possible to follow the course, exchange information, and analyze events of the war via information systems. Through information, it is possible to influence people's consciousness and shape public opinion, by changing people's attitudes, stereotypes, and world-view, and by managing existing public opinion. The effect applied on citizens, government, and opponents by specially selected information for strategic, political, economic, military, or other purposes is referred to as information warfare.

\section{The Analysis of Information Warfare from Viewpoint of Psychology of Perception}

Information emanates on the basis of events around the world. Therefore, information is the result of interpreting and attributing the meaning of perceived events (data). This is done, in some way, to form a clear picture of the event. The more precise the information possessed by each opponent, the more each benefits (Zeynalyan, 2015).

Modern war is not only forced collision, but also a struggle of moral spirit, views, and principles. Acquiring victory is an important factor in the sphere of public consciousness. Psychological struggle wages before military operations, and continues during and even after its completion. The core issue is the imposing of one's own will on the group consciousness of the opponents. The purpose of this impose is to manage the consciousness of military service staff (Margaryan, 2009).

Today's main wars develop in areas outside of military operations. Moreover, armed conflict is emerging in the virtual space. First, virtual heroes enter the battle, and then the informative ones. Shortly after, if necessary, the traditional forces come to the forefront. The information and communication space has become foremost, as this works with the civil population. According to the results of research represented by Pochepcov (2015), the new generation depends on daily news. The $64 \%$ of young Americans watching the news while online and this activity is fifth out of ten others.

\footnotetext{
${ }^{1}$ Nane Zeynalyan, Public Administration Academy of the Republic of Armenia, Yerevan, Armenia, nanezeynalyan@gmail.com
} 
As for perception, Shiffman (2003) defined it as the product of mental processes, which includes concepts of meaning, relationships, context, subjective evaluation, previous individual experience, and memory. Therefore, perception classifies, interprets, and comprehends information received from sensory organs. Perception regulates sensory data, converting it to knowledge about objects and events of the external world. As noted by Kenrick, Neuberg, and Cialdini (2002), even if the person has paid attention to the phenomenon, it is necessary to define and interpret that information.

Our lifestyle is directed towards selective attention and, consequently, the impact of available information. Lifestyle determines attitudes, values, interests, and views, which are developed during our maturation (Zimbardo \& Leippe Michael, 1991).

The theory of cognitive dissonance (Zimbardo \& Leippe Michael, 1991) explains the phenomenon of selective attention: where a person tends to pay maximum attention to a message that strengthens his position, rather than the one that conflicts with it. The contradictory elements of the report create internal conflict, like discomfort, which is explained by dissonance. By focusing on the positive aspects of a chosen position, and rejecting the negatives, we abolish dissonance. In this case, a strengthening message has a supportive effect.

The issue of persuasion is complicated, being related to the idea that acceptance of a message is less dependent on its content than it is on the cognitive reactions caused by its content. The quality of the report in terms of reliability, accuracy, and clarity of the arguments, has special significance. The arguments reported should resist any comparison of knowledge among the audience but rather connect the positions of the audience with the guaranteed opinion. Arguments that are clearly defined and seemingly irrefutable are considered important, as well as those that contain new information on a subject. Messages that meet specific quality standards can have a strong effect. The clearer an argument, the easier the message will be accepted. Every additional argument may generate a desired cognitive response, which will promote acceptance of the message (Zimbardo \& Leippe Michael, 1991).

Representatives of Gestalt psychology emphasize that perception is not the sum of sensations. In addition, characteristics of a figure are not described as characteristics of its parts. Within this thinking, the parts are seen as overall forming the figure or gestalt (a unit). Everything a person does not consciously perceive, becomes a background, and what he sees becomes a figure in that background.

The research conducted by Zeigarnik (1986) has confirmed the hypothesis of Gestalt psychology in that intermittent tasks are remembered better than completed tasks because the former maintains motivational tension. However, this was not always the case as completed, rather than interrupted tasks, were found to be better remembered when there was extremely strong interest in the task itself, while interrupted events were best remembered when there was weak motivation. The experiments later lead to research into a person's self-esteem and motivation, which revealed tasks completed with adequate self-esteem were better remembered than those completed with low or shattered self-esteem.

However, in regard to this principle, media representatives often present incomplete information, which allows control of the person through maintained motivational tension, which preserves a person's interest in the ongoing events.

One component of the information warfare involves psychological operations that use media, radio, and printed materials to suppress the morale of the opponent and influence his consciousness (Margaryan, 2009). The wide dissemination of the internet has had a revolutionary role in advancing the information-psychological warfare. Any information, of which a person becomes aware of, in a very short time, becomes public property. Information may be taken as absolute truth without considering the reliability of the source if it touches the actual needs of the person. In these circumstances, it may be more difficult to manage information and control public opinion.

Today, the issue of psychological safety has arisen in society, due to the growing influence of mass communication. A person not only "uses" information, but also creates it, to some extent, because during their activity, a person self-determines their communication, occupies a certain position, and thus selectively treats the aspects that can influence the course of his entire life. However, the psychological impact can be a threat to their psychological security. In regard to this, Aghuzumtsyan 
et al. (2013) define "psychological safety" as "such conditions of information environment and particular person, group, society, conditions of life in general, which is not conducive to disturbance of social subjects' integrity, adaptation, functioning, and development". This definition also appears in the works of Brushlinskey (1996) and Kabachenko (2002).

Pochepcov (2002) wrote that the phenomenal change in the amount of information used by individuals has not been fully realized. For the person, who initially receives the information on their own, to analyze such independently they need not only facts, but also the interpretation of these facts, since generally such knowledge is beyond his everyday world. The greater the volume of information a person receives, the less an ability they have to control it adequately. Pochepcov (2002) highlights the following periods of increasing volumes of information:

1. A person finds the facts and interprets them;

2. A person obtains facts from someone but can still interpret them independently;

3. One obtains facts and interpretations of the world and tries to fit these into their world model; and

4. One obtains facts and their interpretations, and at the same time, the world model.

Taylor (1999) quotes Douglas Hurd, the British Foreign Minister, as saying that policy is managed, not by events, but by spotlighting the events. Major-General Lewis W. MacKenzie, who led the contingent of UN forces in Bosnia and Herzegovina, also testifies to the fact that "perception is more convincing than the reality".

George Creel (2007), head of the US Committee on Public Information, was distinguished by his systematic approach to campaigning. Modern studies reveal, in his so-called "home-propaganda", the following elements:

- Emotionality, of which a German diplomat writes that Americans are emotional enough, and this is not taken into account by German propagandists;

- Demonization of opponent;

- "A war that will end all wars". This statement was intended for intellectuals and pacifists because they needed a more sophisticated form of impact; and

- Dishonesty, which is always present in propaganda during wartime.

One criterion of efficiency in the field of psychological operations is the ability to form international opinion by the relevant international organizations. Margaryan (2009) emphasized that this is necessary to plan, not only offensive psychological operations, but also a number of defensive measures. Injecting the relevant ideas and values in the consciousness of a person and society can lead to distorting the basis of the world-view and alter vital positions.

Umberto (2005) in his essay, "Comprehending War", mentions several reasons for the impossibility of war, which have emerged after the investigation of atomic energy, television, and air traffic. These are:

1. In modern war there is no front and two opponents; and

2. New communication technologies represent constant a stream of information, and any dictator is unable to stop the stream. The stream of information works as secret services in traditional wars, by reporting the unexpected. Meanwhile, the war is not realistic, if surprising the opponent is excluded.

\section{The Interpretation of the Results of Research on Perception of Information Warfare}

The conducted research aimed to reveal psychological peculiarities in perceiving the information warfare among social groups. The research involved 50 students, aged 18-21, who were studying "Public Administration". This target group was selected because youths are the most active within the information sphere and information reaches them foremost. Apart from this primary importance, the formation of public opinion among youth has relevance, as this demographic group will form the majority of the labor market in the future. The sample consisted of 50 respondents, 37 female and 13 male.

The first stage of the study involved surveying the youth to identify sources of information used most often by young people. The questionnaire comprised six items. This yielded the following results: 16 survey participants noted television (TV) as a basic source of information, 5 used print media, and all 
participants indicated the use of the Internet. Twenty-five survey respondents trusted the information received from $\mathrm{TV}$, two did not trust any source, and two others trusted information they heard from radio broadcasts. Twenty-five respondents noted electronic resources as reliable, including the official media and foreign press. In the series of responses, there were also entertainment websites that provided unreliable information and 38 respondents were certain that Armenian media interpret information other than objectively.

The survey revealed that the majority of respondents followed foreign policy (27 respondents) and internal policy (25 respondents), as well as news connected to the region (15 respondents).

More than half of the respondents (24 respondents) read what they view (mostly news on social networks); 11 without checking the validity of the presented information. Nineteen were satisfied with the information received from a single source, and only three respondents checked information against four or more other sources.

The second phase of the research involved a content analysis of the survey results. This analyzed the website content that most respondents (40) used for information. Respondents of the survey perceived news sources to include "Facebook.com", which is a social media site that includes various media publications, and "blog.1in.am", which has not presented news about politics for a long time. However, analysis only included news.am content (section on Republic of Armenia foreign policy).

Figure 1: The most frequently used media sources

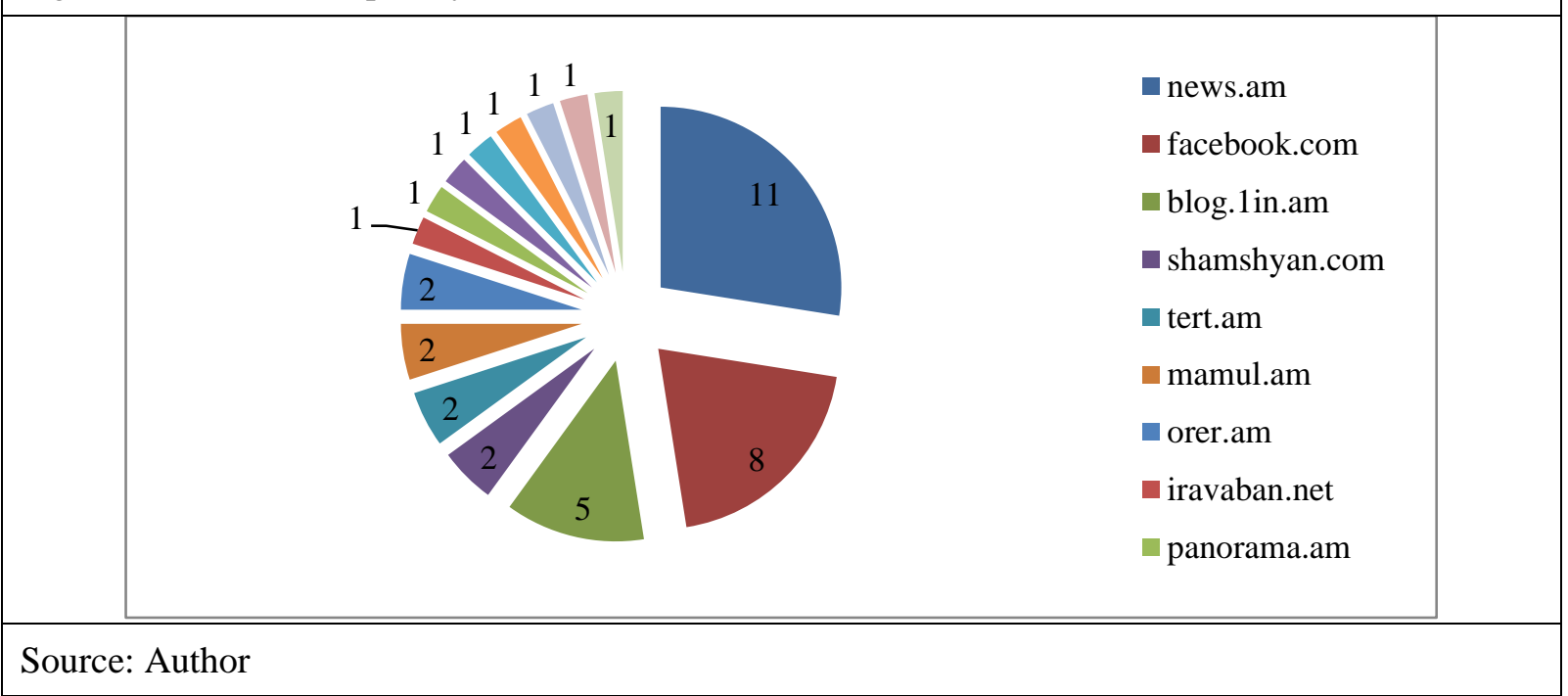

The content analysis was conducted from the survey results for the week, February 20-27, 2016, for which the foreign policy section of the most-used Armenian website (news.am) was recorded in the sample, and thus analyzed. The most often encountered phrases, separated from 52 articles, are presented in the Table 1 . The articles mostly referred to international relations between Armenia and neighboring countries. The research period coincided with the anniversary of massacres in Sumgait in 1988 (February 27-29). From results of the content analysis, it becomes clear that memories of Sumgait, as well as Armenian Genocide, are still fresh in people's minds. The website periodically presents information about the situation in the contact line (line of contact in the conflict) relating to Nagorno-Karabakh and Azerbaijan, e.g. incidents of ceasefire violations and the number of shootings. During international official visits and meetings, politicians talk about Armenian-Turkish and Armenian-Azerbaijan relations. The possibilities of peace-building and regional security, membership of Armenia in European Union, and Eurasian Economic Union are also discussed.

Based on the results of the content analysis, the most often-encountered phrases involved four groups: war, peace, past memories, and future. These formed the basis in the next study stage of free association, which involved the following phrases:

- Conflict

- Armenian massacres 
- Contact line

- Armistice

- Cooperation

- Peace

Table 1: Results of the content analysis in order of relevance

\begin{tabular}{|l|r|}
\hline Unit & Frequency \\
\hline Genocide & 25 \\
\hline Military outpost & 23 \\
\hline Tragedy of Sumgait & 18 \\
\hline Contact line & 11 \\
\hline Opponent & 11 \\
\hline Regional security & 9 \\
\hline Opposing armies & 8 \\
\hline Condemnation & 8 \\
\hline Nagorno-Karabakh conflict & 7 \\
\hline
\end{tabular}

Source: Author

In this next phase, the resulting associations were subjected to psychological analysis. Contradictory views about an issue were often found. The most frequently encountered associations are listed in Table 2 .

Table 2: Associations related to the selected phrases

\begin{tabular}{|c|c|c|c|c|c|}
\hline Conflict & $\begin{array}{c}\text { Armenian } \\
\text { massacres }\end{array}$ & Contact line & Armistice & Cooperation & Peace \\
\hline Battle & Pain & Frontier & Peace & $\begin{array}{c}\text { Coinciding of } \\
\text { interests }\end{array}$ & Quietude \\
\hline Hostility & Cruelty & Armed collision & $\begin{array}{c}\text { Relative } \\
\text { peace }\end{array}$ & $\begin{array}{c}\text { Compromise } \\
\text { Development/Reforms }\end{array}$ & Solidarity \\
\hline Discordance & Slaughter & Communication & $\begin{array}{c}\text { Solidarity } \\
\text { assistance }\end{array}$ & Relationship \\
\hline Casualty & Revenge & Tension & Compromise & $\begin{array}{c}\text { Listening } \\
\text { ability }\end{array}$ & Happiness \\
\hline Tension & $\begin{array}{c}\text { Lack of } \\
\text { unity }\end{array}$ & Similarity & Tension & Trust & \\
\hline
\end{tabular}

Source: Author

Among respondents of the research, the most frequent associations of "conflict" were "battle" and "struggle for victory". As previously mentioned, the research was performed with Armenian youth and the results are likely based on conditioning, as subjects were born during the time of war in the region, and many would have lost their relatives during that time. The frequency of the words "loss" and "hostility" may also relate to this conditioning.

The phrase "Armenian massacre" stirred past memories, with words recorded including genocide, condemnation, revenge, genetic memory, and ethnic and cultural annihilation. Such associations may have presented because Armenia is a genocide-surviving nation.

Associations with "contact line" and "armistice" were rational interpretations of the abovementioned phrases. However, there were also associations relating to communication possibilities, which might indicate a willingness to establish relations with opponents, responsibility, and or expectations that lead to a positive outcome of the conflict.

The results of the association analysis show that cooperation was perceived as a continuous process that requires mutual effort and investment. Meanwhile, peace was considered a result finally achieved 
through quietude. Associations relating to this phrase had mostly positive connotations, since they related to a "bright future", future planning, and hope. Associations in this column, show that peace establishment was desirable but, at the same time, seen as a difficult achievement by the respondents.

The respondents mainly interpreted "cooperation" as a "coinciding of interests". Results indicate that Armenian youth consider cooperation for the purpose of a final conflict settlement between allies and opponents as beneficial.

Interestingly, "tension" appeared frequently in associations with contact line, armistice, and conflict. This phenomenon might be a manifestation of an accumulation of psychological emotions.

\section{Conclusion}

The intensification of a foreign enemy's image can invoke hostility towards the opponent and escalate hostility, or, alternatively, unite a nation. However, it can also threaten the sense of personal safety and cause mass panic among a nation's citizens. Therefore, information in the media about military operations, attacks, violations of ceasefire, and tension in the contact line relating to conflict, may have a negative effect on public opinion.

This theoretical and experimental research enabled us to conclude that the psychological warfare is based mostly upon emotions. The effectiveness of psychological warfare greatly depends on how information is perceived in society. Therefore, in the contemporary world, it is necessary to defend and fight, not only on the battlefield, but also with information weapons. This imposes requirements on psychological science to explore the irregularities around perception of information and find mechanisms to safeguard people's lives by way of orchestrating the formation of necessary attitudes and stereotypes.

\section{References}

Aguzumtsyan, R. V., Amiryan, S. S., Papoyan, V. R., Muradyan, E. B., Galstyan, A. S., \& Sargsyan, D. Y. (2013). Problemy psiholo $\neg$ gičeskoj bezopasnosti ličnosti: teoretičeskie i éksperimental'nye issledovaniâ / Izdatel'stvo EGU, Erevan, 134st., st. 23 [The Issues of Psychological Safety of a Person: theoretichal and experimental researches. Publisher YSU, Yerevan, p 134 - 23].

Brushlinskey, A. B. (1996). Sub"ekt bezopasnosti i bezopasnost' subekta // Problemy informacionno-psihologičeskoj bezopasnosti: Sbornik statej i materialy konferencii. M., s. 41-42. [The Subject of Safety and the Safety of the Subject. The Issues of Information-Psychological Safety: Collection of Articles and Conference Proceedings, p. 41-42.]

Creel, G. (2007). How we advertised America. - San Francisco. Retrieved from

https://archive.org/stream/howweadvertameri00creerich/howweadvertameri00creerich_djvu.txt

Kabachenko, T. S. (2002). Metody psihologičeskogo vozdejstviâ. M.: Pod obŝ.-vo Rossii., 2002, s.4 [Methods of Psychological Impact, Russia, 2002, p. 4].

Kenrick, D. T., Neuberg, S. L., \& Cialdini, R. B. (2002). Social Psychology: Unraveling the Mystery (2nd Ed.). Boston: Allyn \& Bacon.

Margaryan, V. H. (2009). Martakan gorcuneut'yan hogebanut'yun. - Er. : HH PN azgayin razmavarakan hetazotut'yunneri institut, 2009. - 436 ēj [Psychology of Military Activity. The National Institute of Defense and Strategic Studies, 2009, p. 436].

Pochepcov, G. G. (2002). Psihologi"eskie vojny. M.: «Refl-buk», K.: «Vakler»- 528 s.; ISBN 966-543-048-3 (seriâ)

[Psychological Warfare. K.: "Vakler" - p. 528; ISBN 966-543-048-3 (series)].

Pochepcov, G. G. (2015, December). The new civil space information war. Retrieved from http://osvita.mediasapiens.ua/trends/1411978127/novoe_grazhdanskoe_prostranstvo_informatsionnoy_voyny/

Shiffman, H. (2003). Oŝuŝenie i vospriâtie. 5-e izd. - SPb.: Piter, 2003. - 928 s: il. - (Seriâ 《<Mastera psihologii 》). ISBN 5318-00373-7 [Sensation and Perception, 5th ed., Peter, 2003, p. 928: (Series «Mastera psihologii»). ISBN 5-318-00373-7].

Taylor, P. M. (1999). Paper Bullets or Magic Bullet? Psycological Operations and Information Warfare. - Leeds, 1999 // Occasional Paper, 3, Global Transformation Research Group.

Umberto, E. (2005). Pât' ésse na temy étiki / Per. s ital. E. Kostûkovič. - SPb.: Simpozium, 2005. - 160 s. - ISBN 5-89091210-0. (Osmyslââ vojnu) [Five Essays on Ethics, Italy, p. 160 - ISBN 5-89091-210-0. (Conceptualizing the war)].

Zeigarnik, B. V. (1986). Patopsihologiâ: učeb. dlâ vuzov / - 2-e izd., pererab. i dop. - M. : Izd-vo Mosk.un-ta. - 288 s. [Pathopsychology: Manual for Higher Education, 2nd ed, revised, p. 288].

Zeynalyan, N. A. (2015). Teg̉ekatvakan-hogeba`nakan paterazmə orpes paterazmog erkri bnakč‘ ut'yan tagnapi patčar, Tesakan ev kirarakan hogeba $\neg$ nut'yan ardi himnaxn $\neg$ dirnerə, V mi $\neg$ jazgayin gitažoġovi nyut'er, Er., «Ëdit print» hrat., 686 ej, 114-118 [Information - Psychological Warfare as a Reason of Trouble of Population in the Country at War. The Current Issues in Theoretical and Applied Psychology, Vth International Conference Proceedings, Edit Print, 686 pg, 114-118]. Zimbardo, Ph. G., \& Leippe Michael, R. (1991). The psychology of attitude change and social influence. McGraw-Hill series in social psychology. New York, NY, England: Mcgraw-Hill Book Company, pp. 370. 